\title{
Loyalitas Pasien Rawat Inap Melalui Layanan BPJS Kesehatan (Studi pada RSI Jemursari Surabaya)
}

\author{
Putri Mahanani \\ Universitas Nahdlatul Ulama Surabaya \\ email: putrimahanani@unusa.ac.id \\ Denis Fidita Karya \\ Universitas Nahdlatul Ulama Surabaya \\ email: denisfk@unusa.ac.id
}

\begin{abstract}
BPJS is one of the health services provided by the government to the people of Indonesia. In the process of patient care by using BPJS there were some complaints from consumers related to the quality of service. Poor service quality will have an impact on consumer dissatisfaction in the service, so that it is capable of influencing consumer loyalty. Loyalty can only be generated if consumers have experienced the satisfaction of a good service quality provided by the service provider. This study aims to determine the effect of service quality on customer loyalty. In this case the customer satisfaction are things that need to be met first before consumers get to the stage of loyalty. Respondents of this study are inpatients in RSI Jemursari Surabaya as many as 100 people who use the service BPJS third grade. This study used survey method and analyzed using path analysis with Partial Least Square (PLS). Results from this study is the quality of service has an influence on loyalty with mediation of consumer satisfaction. Loyalty can occur if the satisfaction felt by consumers. Thus, in this study, customer satisfaction a mediating variable for the relationship between the variables of service quality and customer loyalty.
\end{abstract}

Keywords: service quality, consumer satisfaction, consumer loyalty

\section{PENDAHULUAN}

Program Badan Penyelenggara Jaminan Sosial (BPJS) Kesehatan yang bergulir sejak awal tahun 2014 merupakan layanan yang paling banyak memperoleh keluhan dari masyarakat (www.jawawapos.com, 2015). Salah satu indikasinya adalah banyaknya laporan yang diterima oleh Komisi Pelayanan Publik (KPP) Jatim. BPJS menduduki peringkat teratas dalam daftar instansi paling dikeluhkan di Jawa Timur (www. kppjatimprov.go.id, 2015).

Mayoritas keluhan tersebut terkait dengan rumitnya prosedur layanan pendaftaran bagi pasien BPJS. Hal selanjutnya yang menjadi keluhan adalah masalah teknis di lapangan, yaitu mengenai jumlah rumah sakit yang masih tergolong rendah yang memberikan layanan untuk pasien BPJS, dan juga persoalan rumah sakit yang belum bisa meng-cover semua kebutuhan pasien (www.kppjatimprov.go.id, 2015).

Keluhan tersebut terjadi karena harapan yang dimiliki konsumen tidak sesuai dengan kenyataan yang terjadi. Hal ini berkaitan dengan perhatian besar yang diberikan oleh masyarakat terhadap regulasi BPJS. Besar kemungkinan informasi terkait segala hal yang 
menyangkut tentang prosedur penggunaan layanan BPJS belum tersampaikan kepada masyarakat secara utuh dan menyeluruh, sehingga banyak hal yang belum diketahui oleh masyarakat terkait dengan prosedur penggunaan layanan BPJS.

Rumah Sakit Islam (RSI) Jemursari Surabaya adalah salah satu rumah sakit di Surabaya yang menyediakan layanan BPJS Kesehatan bagi masyarakat. RSI Jemursari Surabaya dan BPJS bersama-sama berkomitmen melayani masyarakat kelas menengah ke bawah dengan pelayanan yang terjangkau, termasuk pelayanan berbiaya tinggi, seperti hemodialisa (cuci darah), bedah, jantung, dan lain sebagainya. Dengan adanya BPJS, jumlah pasien keseluruhan yang menggunakan layanan RSI Jemursari meningkat dari 31\% menjadi 63\%. Pasien BPJS rawat inap meningkat cukup tinggi dari 41\% menjadi 74\%. Khusus untuk pasien hemodialisa (cuci darah) justru meningkat drastis dari 264 pada Januari 2014 menjadi 709 pasien pada Desember 2014, sedangkan di tahun 2015 angka pasien hemodialisa yang menggunakan BPJS telah mencapai angka ribuan (www.harianterbit.com, 2015).

Hal tersebut menunjukkan bahwa BPJS merupakan program yang bermanfaat untuk masyarakat kelas menengah ke bawah, namun RSI Jemursari Surabaya juga tidak mengalami kerugian dengan mengadakan program tersebut, melalui manajemen yang berbasis pelayanan publik justru RSI Jemursari Surabaya memperoleh keuntungan lebih dengan adanya program BPJS. Senada dengan hal tersebut, Direktur RSI Jemursari mengatakan manajemen berbasis pelayanan publik mengacu pada komitmen dokter, kebersamaan dalam perencanaan obat dan kebutuhan lainnya, serta kendali mutu. Selain itu, kualitas pelayanan tidak rendah, meski RSI Jemursari melayani masyarakat rendahan (www. harianterbit.com, 2015).

Pelayanan merupakan unsur yang sangat penting di dalam usaha meningkatkan kepuasan konsumen. Pada dasarnya posisi pelayanan ini merupakan faktor pendukung terhadap aktivitas pemasaran jasa RSI Jemursari. Untuk itu RSI Jemursari Surabaya memberikan perhatian khusus kepada kegiatan pelayanan dalam hal pemenuhan kebutuhan pelanggan agar dalam pelaksanaannya dapat memuaskan pelanggannya.

Jika pelayanan yang diberikan memenuhi harapan konsumen, maka konsumen akan merasa puas dan bila kualitas pelayanan berada di bawah tingkat yang diharapkan, pelanggan akan merasa kurang atau tidak puas. Pelanggan yang merasa tidak puas terhadap kualitas pelayanan yang diberikan, dengan sendirinya akan menceritakan kepada orang lain sebagai komplain atas ketidakpuasan tersebut (word of mouth negative).

Kualitas layanan merupakan topik yang paling banyak menarik minat tidak hanya bagi praktisi namun juga ilmuwan atau akademisi untuk menelitinya, teori ini dipopulerkan oleh Parasuraman dkk. (1985). Lehtinen dan Lehtinen (1982) menilai bahwa dimensi kualitas layanan bisa dilihat dari tiga hal yaitu, interaksi, bukti fisik, dan kualitas perusahaan. Kepuasan pelanggan adalah keputusan akhir dari pengalaman konsumen yang merasakan adanya kualitas layanan (Bolton dan Drew, 1991; Boulding, dkk., 1993).

Oleh karena itu, pengukuran kepuasan akan pelayanan yang diberikan oleh RSI Jemursari Surabaya pada masyarakat harus selalu dilakukan. Hal tersebut bertujuan untuk mengetahui dan merencanakan strategi yang lebih baik di masa mendatang, lebih meningkatkan 
kualitas pelayanannya agar dapat memenuhi kebutuhan dan keinginan konsumen, serta untuk meminimalisir adanya komplain atau keluhan dari konsumen. Berdasarkan hal tersebut, perlu dikaji lebih mendalam mengenai kualitas layanan yang telah diberikan oleh RSI Jemursari Surabaya terhadap pasien yang menggunakan layanan BPJS, terutama untuk pasien rawat inap karena pasien rawat inap bisa dikategorikan konsumen yang telah merasakan seluruh layanan yang diberikan oleh pihak rumah sakit, terutama pada tingkat fasilitas kesehatan tertentu.

Berdasarkan latar belakang masalah yang telah disajikan sebelumnya, maka rumusan masalah yang dapat dikemukakan adalah sebagai berikut:

1. Apakah kualitas layanan berpengaruh terhadap loyalitas konsumen melalui kepuasan konsumen?

2. Apakah kualitas layanan berpengaruh terhadap loyalitas konsumen?

\section{KERANGKA TEORITIS}

\section{Definisi Kualitas Layanan}

Memberikan layanan terhadap konsumen dapat terjadi dengan adanya interaksi antara konsumen dengan karyawan, hal tersebut merupakan suatu aktifitas atau serangkaian aktifitas yang bersifat tidak kasat mata (Ratminto dan Winarsih, 2005). Kegiatan ini bertujuan sebagai salah satu upaya perusahaan dalam memenuhi kebutuhan konsumennya sehingga sesuai dengan harapan yang diinginkan oleh konsumen.

Definisi lain dari kualitas layanan adalah tingkat keunggulan yang diharapkan oleh pelanggan untuk memenuhi keinginan pelanggan (Wyckof, 1990 dalam Tjiptono, 2005).

Dalam salah satu studi yang dilakukan oleh (Parasuraman, dkk., 1988) terdapat lima dimensi kualitas layanan yang dapat dijabarkan yaitu sebagai berikut:

1. Keandalan (Reliability), yaitu kemampuan perusahaan untuk memberikan pelayanan sesuai yang dijanjikan secara akurat dan terpercaya. Kinerja harus sesuai dengan harapan pelanggan yang berarti ketepatan waktu, pelayanan yang sama untuk semua pelanggan tanpa kesalahan, sikap yang simpatik, dan dengan akurasi yang tinggi.

2. Keresponsifan (Responsiveness), yaitu suatu kemampuan untuk membantu dan memberikan pelayanan yang cepat (responsif) dan tepat kepada pelanggan, dengan penyampaian informasi yang jelas. Membiarkan konsumen menunggu tanpa adanya suatu alasan yang jelas menyebabkan persepsi yang negatif dalam kualitas pelayanan.

3. Jaminan (Assurance), atau kepastian yaitu pengetahuan, kesopansantunan, dan kemampuan para pegawai perusahaan untuk menumbuhkan rasa percaya para pelanggan kepada perusahaan. Terdiri dari beberapa komponen antara lain komunikasi (communication), kredibilitas (credibility), keamanan (security), kompetensi (competence), dan sopan santun (courtesy).

4. Bukti fisik (Tangibles), yaitu kemampuan suatu perusahaan dalam menunjukkan eksistensinya kepada pihak eksternal. Penampilan dan kemampuan sarana dan prasarana fisik perusahaan dan keadaan lingkungan sekitarnya adalah bukti nyata dari pelayanan yang diberikan oleh pemberi jasa. Yang meliputi fasilitas fisik (gedung, gudang, 
dan lain-lain), perlengkapan dan peralatan yang dipergunakan (tekhnologi), serta penampilan pegawainya.

5. Empati (Empathy), yaitu memberikan perhatian yang tulus dan bersifat individual atau pribadi yang diberikan kepada para pelanggan dengan berupaya memahami keinginan pelanggan. Dimana suatu perusahaan diharapkan memiliki pengertian dan pengetahuan tentang pelanggan, memahami kebutuhan pelanggan secara spesifik, serta memiliki waktu pengoperasian yang nyaman bagi pelanggan.

\section{Definisi Kepuasan Pelanggan}

Tingginya tingkat persaingan dan daya beli konsumen terhadap suatu produk menyebabkan kepuasan konsumen menjadi hal yang sangat diperhatikan bagi pemasar. Pemasar, konsumen dan peneliti perilaku konsumen adalah pihak-pihak yang paling banyak berhubungan langsung dengan kepuasan atau ketidakpuasan pelanggan (Tjiptono, 2005). Karena kepuasan konsumen menggambarkan sejauh mana persepsi konsumen terhadap kinerja suatu produk atau jasa sehingga dapat memenuhi harapan kebutuhan konsumen (Kotler, 2006). Dengan kata lain, jika kinerja produk yang diberikan oleh perusahaan lebih rendah daripada harapan konsumen, maka ketidakpuasan konsumen akan terjadi, namun sebaliknya jika kinerja dan segala atribut yang melekat pada suatu barang atau jasa sesuai atau melebihi harapan konsumen, maka kepuasan konsumen akan tercapai.

\section{Definisi Loyalitas Pelanggan}

Tjiptono (2005:387) mendefinisikan loyalitas sebagai situasi dimana konsumen bersikap positif terhadap produk atau produsen (penyedia jasa) serta disertai pola pembelian ulang yang konsisten. Loyalitas juga dinyatakan sebagai suatu perilaku yang diharapkan atas suatu produk atau layanan yang antara lain meliputi kemungkinan pembelian lebih lanjut atau perubahan perjanjian layanan, atau sebaliknya seberapa besar kemungkinan pelanggan akan beralih kepada merek lain atau penyedia jasa lain (Tjiptono, 2005).

\section{Hipotesis}

Gronroos (1984, 1990) dan Parasuraman, dkk. $(1985,1988,1994)$ berpendapat bahwa persepsi kualitas layanan dihasilkan dari perbandingan yang dibuat oleh konsumen antara kualitas yang diharapkan dan kualitas yang dirasakan. Kualitas layanan tersebut yang pada akirnya akan menghasilkan kepuasan atau ketidakpuasan dari konsumen. Kualitas layanan sepertinya menjadi satu-satunya faktor layanan yang memiliki pengaruh langsung pada kepuasan konsumen (Cronin dan Taylor, 1992; Ruyter, dkk. 1997; Spreng dan Mackoy, 1999). Secara keseluruhan, kepuasan yang diperoleh dalam pengalamannya memperoleh suatu pelayanan jasa akan menyebabkan munculnya loyalitas konsumen (Bearden dan Teel, 1983). Hal tersebut yang akhirnya membentuk hipotesis pertama dan kedua, yaitu:

$\mathrm{H}_{1}$ : Kualitas layanan berpengaruh terhadap loyalitas konsumen melalui kepuasan konsumen

$\mathbf{H}_{2}$ : Kualitas layanan berpengaruh terhadap loyalitas konsumen

Hipotesis tersebut dapat digambarkan pada rerangka konseptual penelitian di bawah ini: 


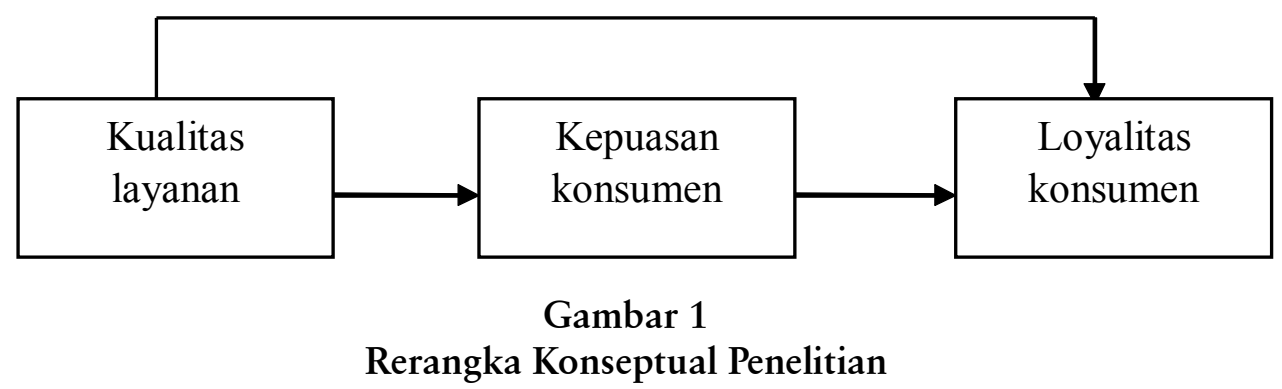

Rerangka konseptual tersebut menunjukkan pengaruh variabel independen berupa kualitas layanan terhadap variabel tergantung yaitu loyalitas konsumen, dengan kepuasan konsumen sebagai variabel mediasi.

\section{METODE PENELITIAN}

Metode penelitian yang digunakan dalam penelitian ini adalah metode survey, informasi dikumpulkan dari responden dengan menggunakan kuisioner. Kuesioner terdiri dari beberapa item pernyataan untuk mengukur kualitas layanan, kepuasan dan loyalitas konsumen.

Responden dari penelitian ini adalah pasien rawat inap BPJS di RSI Jemursari Surabaya berjumlah 100 orang, yang terdiri dari 50 pasien laki-laki, dan 50 pasien perempuan. Jumlah sampel sebanyak 100 orang ditentukan dengan mengacu pada ukuran sampel dalam penelitian multivariat yang ditulis oleh Uma Sekaran (2006) yang mengatakan bahwa ukuran sampel sebaiknya 10 kali lebih besar dari jumlah variabel dalam penelitian. Jumlah variabel dalam penlitian ini adalah tiga sehingga akan lebih baik jika jumlah sampel minimal yang dapat digunakan adalah $10 \times 3=30$ orang. Responden dipilih dengan menggunakan metode gabungan antara purposive sampling dengan convenience sampling. Metode purposive sampling yaitu dengan melakukan sampling yang terarah dengan memilih populasi berupa pasien rawat inap BPJS RSI Jemursari yang memiliki karakteristik yang sama. Sedangkan convenience sampling ini memberi kebebasan kepada peneliti untuk memilih siapa saja yang ditemui menjadi partisipan (Cooper dan Schindler, 2001:192).

Dalam penelitian ini data dari hasil survey akan diolah menggunakan teknik analisis berupa Path Analysis dengan Partial Least Square (PLS), dimana software yang akan digunakan adalah SmartPLS 2.0. Sebelum survey dijalankan, dilakukan uji validitas dan reliabilitas untuk menilai item-item yang digunakan apakah sudah memenuhi syarat validitas dan reliabilitas.

\section{ANALISIS DAN PEMBAHASAN}

Sebelum melakukan pengujian terhadap hipotesis, maka dilakukan uji validitas dari item-item alat ukur. Berdasarkan outer loading untuk semua alat ukur dari masing-masing variabel yaitu kualitas layanan, kepuasan dan loyalitas konsumen dinyatakan valid yaitu memenuhi cut off value sebesar 0,5.

Setelah menguji validitas dari alat ukur, selanjutnya adalah menguji reliabilitas dengan melihat skor composite reliability. Composite reliability menguji nilai reliabilitas masingmasing indikator.Cutoff value dari reliabilitas adalah sebesar 0,7 . 
Tabel 1 Composite Reliability

\begin{tabular}{|c|c|}
\hline Variabel & Composite Reliability \\
\hline Kepuasan pelanggan & 0,9827 \\
\hline Kualitas layanan & 0,9787 \\
\hline \hline Loyalitas & 0,9405 \\
\hline
\end{tabular}

Sumber: Data diolah

Berdasarkan tabel di atas dapat diketahui bahwa tidak ada nilai yang berada di bawah cut off value. Nilai tersebut menyatakan bahwa semua item alat ukur dari masing-masing variabel memenuhi standar reliabilitas.

\section{Uji Hipotesis}

Berdasarkan rumusan masalah yang telah dituliskan, maka penelitian ini memiliki dua hipotesis. Dalam path coefficient ini nilai cutoff value dapat dilihat pada tabel $t$-statistic. Jika $t$-statistics memiliki nilai lebih besar atau sama dengan 1,64 maka pengaruh variabel tersebut adalah signifikan, sedangkan jika kurang dari 1,64 maka dapat dikatakan variabel tersebut tidak berpengaruh secara signifikan.
Berdasarkan hasil uji hipotesis yang tertera pada tabel di atas, diketahui bahwa kualitas layanan berpengaruh terhadap kepuasan pelanggan, dan kepuasan pelanggan berpengaruh terhadap loyalitas konsumen, dengan kata lain kualitas layanan berpengaruh terhadap loyalitas konsumen melalui kepuasan konsumen. Hal ini terbukti dari nilai $t$-statistics yang lebih dari 1,64.

Sedangkan untuk hipotesis kedua yaitu apakah kualitas layanan berpengaruh secara langsung terhadap loyalitas konsumen, dari hasil olah statistik dapat dilihat bahwa nilai $t$ statistics dari hubungan antara kualitas layanan dan loyalitas konsumen adalah kurang dari 1,64. Dengan kata lain, kualitas layanan tidak berpengaruh secara signifikan terhadap loyalitas konsumen.

Tabel 2 Path Coefficient

\begin{tabular}{|c|c|c|}
\hline & Original Sample (O) & T Statistics (|O/STERR|) \\
\hline $\begin{array}{c}\text { Kualitas layanan -> } \\
\text { kepuasan konsumen }\end{array}$ & $\mathbf{0 , 8 8 5 5 1 8}$ & $\mathbf{2 5 , 4 9 5 5 3 8 *}$ \\
\hline $\begin{array}{c}\text { Kepuasan konsumen } \\
->\text { loyalitas konsumen }\end{array}$ & $\mathbf{0 , 8 7 2 9 1 7}$ & $\mathbf{8 , 6 2 3 5 1 4 *}$ \\
\hline $\begin{array}{c}\text { Kualitas layanan -> } \\
\text { loyalitas konsumen }\end{array}$ & $\mathbf{0 , 0 0 7 1 8 3}$ & $\mathbf{0 , 0 6 8 8 5 2}$ \\
\hline
\end{tabular}

Sumber: Data diolah 
Tabel 3 Ringkasan Hasil Penelitian

\begin{tabular}{|c|l|c|}
\hline No. & \multicolumn{1}{|c|}{ Hipotesis } & Kesimpulan \\
\hline 1. & $\begin{array}{l}\text { Kualitas layanan berpengaruh terhadap loyalitas } \\
\text { konsumen melalui kepuasan konsumen }\end{array}$ & Diterima \\
\hline 2. & $\begin{array}{l}\text { Kualitas layanan berpengaruh terhadap loyalitas } \\
\text { konsumen }\end{array}$ & Ditolak \\
\hline
\end{tabular}

Sumber: Data diolah

Setelah melalui serangkaian proses pengumpulan data dan pengujian maka ringkasan hasil penelitian ini adalah seperti yang tertera di pada Tabel 3.

\section{Diskusi}

Pengaruh Kualitas Layanan Terhadap Loyalitas Konsumen Melalui Kepuasan Konsumen

Berdasarkan hasil analisis data, diketahui bahwa hipotesis pertama dalam penelitian ini diterima, dengan kata lain kualitas layanan berpengaruh terhadap loyalitas konsumen melalui kepuasan konsumen. Hal ini sesuai dengan teori yang disampaikan oleh (Bearden dan Teel, 1983) yang menyatakan bahwa secara keseluruhan, kepuasan yang diperoleh dalam pengalamannya memperoleh suatu pelayanan jasa akan menyebabkan munculnya loyalitas konsumen. Dengan demikian dapat disimpulkan bahwa loyalitas konsumen dapat terjadi apabila konsumen telah mengalami kepuasan yang ditimbulkan dari adanya kualitas layanan yang baik.

\section{Pengaruh Kualitas Layanan Terhadap Loyali- tas Konsumen}

Selanjutnya diketahui berdasarkan hasil analisis data bahwa hipotesis kedua dalam penelitian ini adalah ditolak, yang artinya kualitas layanan tidak memiliki pengaruh secara langsung terhadap loyalitas konsumen. Hal ini menjelaskan bahwa loyalitas hanya dapat terjadi apabila konsumen telah merasakan kepuasan terhadap kualitas layanan yang diberikan, sehingga tanpa adanya kepuasan, loyalitas tidak dapat terjadi dengan begitu saja. Dapat diketahui bahwa indikator loyalitas seperti yang dijabarkan oleh Bearden dan Teel (1983), bahwa kepuasan dapat membuat konsumen untuk melakukan pembelian atau penggunaan ulang pada suatu produk dan melakukan word of mouth positif pada orang lain.

\section{IMPLIKASI DAN KETERBATASAN}

Dalam hal ini dapat disimpulkan bahwa kualitas layanan berpengaruh terhadap loyalitas konsumen melalui kepuasan konsumen. Namun demikian, kualitas layanan tidak berpengaruh secara langsung terhadap loyalitas konsumen.

\section{Saran Bagi Penelitian Selanjutnya}

Penelitian ini merupakan pengembangan dari penelitian sebelumnya milik Albert Caruana (2000). Dalam penelitian Albert Caruana (200) dinyatakan bahwa kualitas layanan 
memiliki pengaruh terhadap kepuasan dan loyalitas konsumen. Dalam hal ini kualitas layanan adalah satu-satunya hal yang bisa menimbulkan kepuasan dan loyalitas konsumen. Hal yang bisa dikembangkan dalam penelitian selanjutnya adalah terkait dengan image baik itu coprorate image maupun brand image dari sebuah instansi atau sebuah produk.

\section{Implikasi Bagi Praktisi}

Kualitas layanan kesehatan yang diberikan oleh pemerintah Indonesia melalui instansiinstansi kesehatan yang terkait memberikan dampak secara tidak langsung terhadap image dari pemerintah Indonesia sendiri dan juga instansi yang memberikan layanan jasa kesehatan tersebut yaitu rumah sakit dan instansi sejenisnya. Sehingga hal ini menjadi penting bagi instansi penyedia layanan kesehatan untuk memperhatikan masalah kualitas layanan yang diberikan, akan sangat baik apabila kualitas layanan yang diberikan mampu mendekati atau melampaui harapan dari konsumen, karena hal ini yang akan menciptakan kepuasan dan selanjutnya adalah loyalitas konsumen pada instansi kesehatan terkait, serta image dari intansi kesehatan terkait dan pemerintah Indonesia.

\section{Implikasi Bagi Akademisi}

Dalam penelitian Albert Caruana (200) dinyatakan bahwa kualitas layanan memiliki pengaruh terhadap kepuasan dan loyalitas konsumen. Dalam hal ini dapat diketahui bahwa kepuasan akan menimbulkan loyalitas pada sebuah produk. Hal lain yang kemungkinan dapat berpengaruh terhadap loyalitas dari konsumen terhadap suatu produk terutama yang memiliki asosiasi dengan lembaga Islam seperti
RSI Jemursari yang dapat diasosiasikan dengan salah satu lembaga Islam yang ada di Indonesia yaitu Nahdlatul Ulama, adalah tingkat religiusitas sesorang. Jadi perlu untuk diteliti secara lebih mendalam terkait kemungkinan adanya faktor yang mempengaruhi loyalitas selain dari kepuasan konsumen yaitu tingkat religiusitas konsumen.

\section{Keterbatasan}

Keterbatasan dalam penelitian ini adalah hanya mengambil sampel dari satu jenis tingkat fasilitas kesehatan BPJS yaitu tingkat tiga, akan lebih baik jika diambil sampel dari keseluruhan tingkat dari fasilitas kesehatan, yaitu mulai tingkat satu, dua, dan tiga agar hasil yang diperoleh dapat lebih menggambarkan kualitas layanan BPJS secara keseluruhan dari beberapa tingkat fasilitas kesehatan yang dimiliki.

\section{DAFTAR REFERENSI}

Bearden, W.O dan Teel, J.E. 1983. Selected Determinants of Consumer Satisfaction And Complaint Behaviour. Journal of Marketing Research, Vol.20, February, pp.21-8.

Bolton, R.N, dan Drew J.H. 1991. A Multistage Model of Customers Assesments of Service Quality And Value. Journal of Consumer Research, Vol17, March, pp.375-84.

Boulding, W., dkk. 1993. A Dynamic Process Model of Service Quality: From Expectations to Behavioural Intentions. Journal of Marketing Research, Vol.30, February, pp. 7-27.

Caruana, Albert. 2002. Service Loyalty: The Effects of Service Quality And The Mediating Role of Customer Satisfaction. 
European Journal of Marketing, August.

Cronin, J.J dan Taylor S.A. 1992. Measuring Service Quality: A Re-Examination And Extension. Journal of Marketing, Vol.56, July, pp.55-68.

Cooper, D. R., dan Pamela S. S. 2001. Business Research Methods. New York: Mc Graw Hill.

Gronroos, C. 1984. A Service Quality Model And Its Markets Implications. European Journal of Marketing, Vol.18, No.4, pp.36-44.

Gronroos, C. 1990. Service Management And Marketing. DC. Heath and Co., Lexington, MA.

Kotler, Philip. 2005. Manajemen Pemasaran Edisi 11. Jakarta: PT. Indeks.

Lehtinen, U dan Lehtinen, J.R. 1982. Service Quality-A Study of Dimensions. Unpublish working paper, Service Management Institute, Helsinki, pp.439-60.

Parasuraman, dkk. 1985. A Conceptual Model of Service Quality and Its Implication for Future Research. Journal of Marketing, Vol.49, April, pp.41-50.

Parasuraman, dkk. 1988. Servqual: A Multiple Item Scale for Measuring Consumer Perceptions of Service Quality. Journal of Retailing, Vol.64, No.1, Spring, pp.12-140.
Parasuraman, dkk. 1994. Alternative Scales for Measuring Service Quality: A Comparative Assesment Based On Psycometric And Diagnostic Criteria. Journal of Retailing, Vol.70, No.3, pp.20130.

Ratminto dan Winarsih Atik Septi. 2005. Manajemen Pelayanan. Yogyakarta: Penerbit Pustaka Pelajar.

Ruyter, dkk. 1997. Merging Service Quality And Service Satisfaction: An Empirical Test of An Integrative Model. Journal of Economic Psycology, Vol.18, pp.387406.

Sekaran, Uma. 2006. Metodologi Penelitian Untuk Bisnis. Jakarta: Salemba Empat.

Spreng, M.K dan Mackoy, R.D. 1996. An Empirical Examination of A Model of Perceived Service Quality And Satisfaction. Journal of Retailing, Vol.72, No.2, pp.201-14.

Tjiptono, Fandy. 2005. Service, Quality, and Satisfaction. Yogyakarta: Penerbit Andi. Tanpa nama. 2015. Keluhan BPJS Tertinggi. www.jawapos.com. Diakses tanggal 2 Februari 2016

Tanpa nama. 2015. Tanpa Judul. www.kppjatimprov.go.id. Diakses tanggal 2 Februari 2016

Tanpa nama. 2015. Tanpa Judul. www.harianterbit.com. Diakses tanggal 2 Februari 2016 
Business and Finance Journal, Volume 1, No. 1, March 2016 